\title{
RISK ASSESSMENT PERUSAHAAN EXPORT SEPATU PADA BAGIAN LINE UPPER PT. X
}

\author{
Novita Dewi Vebriyana Dankis dan Mulyono \\ Departemen Keselamatan dan Kesehatan Kerja \\ Fakultas Kesehatan Masyarakat Universitas Airlangga \\ E-mail: dksoty@yahoo.co.id
}

\begin{abstract}
Revolution in the industry sector has been rapidly grown to fill up all the needs of the consumer products. One involves supporting advanced machinery such as "Cutting, Skiving, Stitching, Emboss Logo, Roving, Punch Hole, Juki, Brushing Edge, Hammer Over Lapping and Two Molding”. In the factory production process, there are various types of high-risk activities, especially on line upper. The main of this research is to study the risk assessment on export companies line the upper part of the shoes export company using Job Safety Analysis. This research was conducted observational crosssectional design. Observations made to the hazards and control measures. Interviews were conducted to 12 employees. Variables in this research is production activity, hazard identification, risk assessment, risk control and residual risk. The results of hazard identification has been done, there are 91 known potential hazards, for risk assessment found 7 high risk and low risk 5. Machine classified as high risk on the risk assessment is roving machine, whereas low-risk is two molding machine. Control efforts on the upper line in accordance with the hierarchy of controlling a number of 91 controls, whereas for the residual risk still remains as much as 30 residual risk. Control has been applied quite well by pressing the consequences of hazards and risk management.
\end{abstract}

Keywords: risk assessment, controlling, residual risk

\begin{abstract}
ABSTRAK
Revolusi di bidang Industri telah berkembang pesat untuk memenuhi segala kebutuhan produk konsumen. Salah satu pendukungnya melibatkan mesin-mesin canggih seperti, “Cutting, Skiving, Stitching, Emboss Logo, Roaving, Punching Hole, Juki, Brushing Edge, Hammer Over Lapping dan Two Molding”. Pada proses produksi pabrik ini terdapat berbagai jenis aktivitas yang berisiko tinggi terutama pada line upper. Tujuan dari penelitian ini adalah mempelajari risk assessment pada perusahaan export sepatu pada bagian line upper menggunakan metode Job Safety Analysis. Penelitian ini dilakukan secara observasional dengan rancangan cross sectional. Observasi dilakukan terhadap sumber bahaya dan upaya pengendalian. Wawancara dilakukan kepada 12 karyawan. Variabel pada penelitian ini adalah aktivitas produksi, identifikasi bahaya, penilaian risiko, pengendalian risiko dan risiko sisa. Hasil dari identifikasi bahaya yang telah dilakukan, diketahui terdapat 91 potensi bahaya, untuk penilaian risiko ditemukan 7 berisiko tinggi dan 5 berisiko rendah. Mesin tergolong berisiko tinggi pada risk assessment ini adalah mesin Roving, sedangkan yang berisiko rendah adalah mesin Two molding. Upaya pengendalian pada bagian line upper telah sesuai dengan Hierarki pengendalian sejumlah 91 pengendalian, sedangkan, untuk residual risk masih menyisakan sebanyak 30 risiko sisa. Pengendalian telah diaplikasikan dengan cukup baik dengan menekan konsekuensi bahaya dan manajemen risiko.
\end{abstract}

Kata kunci: penilaian risiko, pengendalian, risiko sisa

\section{PENDAHULUAN}

Revolusi Industri merupakan bentuk kemajuan industri dalam memenuhi kebutuhan dan kehidupan produksi. Tenaga kerja inilah yang menjadi pusat motor usaha produksi untuk menciptakan suatu barang yang berkualitas. Keselamatan dan kesehatan kerja (K3) merupakan syarat mutlak yang harus diperhatikan dan dilaksanakan, untuk mencegah terjadinya berbagai masalah yang disebabkan oleh potensi bahaya di tempat kerja.
Manajemen risiko K3 adalah upaya mengelola risiko aspek K3, menurut (Suma'mur, 2009) untuk mencegah terjadinya kecelakaan yang tidak diinginkan secara komprehensif, terencana dan terstruktur dalam suatu sistem yang baik.

Keselamatan dan kesehatan kerja menurut ILO: Occupational safety and health (OSH) is generally defined as the science of the anticipation, recognition, evaluation and control of hazards arising in or from the workplace that could impair the health and well-being of workers, taking into 
account the possible impact on the surrounding communities and the general environment (dalam Alli, 2008: viii)

Jadi, dapat disimpulkan dari beberapa definisi para ahli bahwa definisi dari keselamatan dan kesehatan kerja adalah suatu ilmu dan penerapannya mengenai pencegahan, pengenalan, penilaian dan pengendalian potensi bahaya yang muncul disebabkan oleh pekerjaan dan keadaan lingkungan kerja yang dapat mempengaruhi kondisi pekerja baik kesehatan maupun produktivitasnya serta dapat pula mempengaruhi masyarakat sekitar dan lingkungannya (Ilfani, 2013).

Definisi manajemen risiko atau risk management menurut ILO (2013), adalah semua tindakan yang diambil untuk mencapai, mempertahankan atau meningkatkan keamanan dari mulai instalasi hingga operasinya. Sedangkan menurut Risk Management Standard AS/NZS 4360:2004 dalam Australian/ New Zealand Standard (2004), risk management adalah budaya, proses dan struktur yang diarahkan menuju kesadaran terhadap peluang potensial sambil mengelola efek samping yang terjadi dari peluang potensial tersebut.

Salah satu sistem manajemen K3 yang global yaitu OHSAS 18001 (Occupational Health and Safety Assessment Series-18001). OHSAS 18001 manajemen risiko sebagai upaya terpadu untuk mengelola risiko yang ada dalam aktivitas perusahaan.

Menurut Risk Management Standard AS/ NZS 4360 (Ramli, 2010) mengelola risiko harus dilakukan secara komprehensif melalui pendekatan manajemen risiko yaitu penentuan konteks dan identifikasi bahaya.

Indonesia memiliki kebijakan $\mathrm{K} 3$ yang diatur dengan Kepmenaker No. 05/1996, diberlakukan Sistem Manajemen Kesehatan dan Keselamatan Kerja yang disebut SMK3 sama dengan OHSAS 18001 Suatu sistem manajemen K3 berintikan manajemen risiko, timbul dari aspek K3 karena terdapat risiko yang harus dikelola dan sebaliknya jika tidak ada bahaya, artinya tidak ada risiko dan manajemen risiko tidak diperlukan.

Hazard atau Bahaya adalah sesuatu yang berpotensi menyebabkan kerusakan, baik halhal yang mencakup zat atau mesin, metode kerja, maupun aspek lain dalam organisasi. Bahaya juga dapat dimaksud segala sesuatu termasuk situasi atau tindakan yang berpotensi menimbulkan kecelakaan atau cidera pada manusia, kerusakan atau gangguan lainnya (Ramli, 2010).
Dapat disimpulkan bahaya adalah situasi ataupun keadaan yang berpotensi menimbulkan kerusakan atau kerugian material atau fisik yang bisa terjadi bersamaan atau kombinasi keadaan di tempat kerja. Jenis bahaya yang ditimbulkan bermacammacam jenisnya dapat berupa bahaya fisik, kimia, ergonomi, psikologis, biologi (Tarwaka, 2010).

Sasaran utama program K3 adalah mengelola risiko untuk mencegah terjadinya kecelakaan atau hal yang tidak diinginkan melalui proses identifikasi bahaya, penilaian risiko dan pengendaliannya. Berdasarkan itu maka, ada empat unsur penting yaitu manusia, sarana, proses dan prosedur.

Pengidentifikasian bahaya sebelum bahaya merupakan inti dari sebuah kegiatan pencegahan kecelakaan. Akan tetapi, identifikasi ini bukan ilmu yang pasti tapi merupakan kegiatan subjektif di mana bahaya yang teridentifikasi bisa saja berbeda antara satu orang dengan yang lainnya. Dari inspeksi sebelumnya dapat dibandingkan atau dikembangkan sehingga sebagai bahan acuan tindakan korektif.

Teknik untuk mengidentifikasi bahaya terbaik menggunakan metode ini, karena mencari bahaya sebelum bahaya tersebut ditimbulkan atau merugikan. Perkembangan ilmu pengetahuan dihasilkan metode proaktif antara lain ${ }^{1}$ Analisis bahaya awal (Preliminary Hazards Analysis-PHA) yaitu mengidentifikasi bahaya yang dinilai dapat mengganggu suatu aktivitas, fasilitas atau sistem, ${ }^{2}$ Analsis pohon kegagalan (Fault Tree AnalysisFTA) yaitu melakukan identifikasi harus menetapkan kejadian puncak/top event yang mungkin terjadi dalam sistem atau proses terlebih dahulu, ${ }^{3}$ Analisis What If Analysis- WIA yaitu mengidentifikasi kemungkinan adanya kejadian yang tidak diinginkan dan menimbulkan suatu konsekuensi serius. ${ }^{4}$ Analisis Model Kegagalan dan efek (Failure Mode and Effect Analysis-FMEA) yaitu menilai potensi kegagalan dalam produk dan proses, ${ }^{5}$ Hazops (Hazard and Operability Study) yaitu teknik identifikasi bahaya yang digunakan untuk industri proses seperti industri kimia, petrokimia dan kilang minyak, ${ }^{6}$ Analisis Keselamatan Pekerjaan (Job Safety Analysis) yaitu teknik untuk mengidentifikasi dan menganalisis bahaya dalam suatu pekerjaan, ${ }^{7}$ Brainstorming, Metode ini mempertemukan kelompok atau tim kerja baik dalam satu bidang yang sama maupun pada lintas fungsi. Dalam pertemuan ini dibahas kondisi di tempat kerja hingga semua anggota kelompok berkesempatan mengemukakan pendapat atau temuannya mengenai bahaya yang ada di lokasi kerja dan terakhir ${ }^{8}$ Analisis Risiko Pekerjaan (Task 
Risk Analysis-TRA) yaitu menganalisis risiko untuk mengetahui besarnya potensi bahaya yang timbul selama kegiatan berlangsung.

Menurut Tarwaka (2008), risiko didefinisikan sebagai suatu kemungkinan terjadinya kecelakaan atau kerugian pada periode waktu tertentu atau siklus operasi tertentu, sedangkan menurut OHSAS 18001 (2007), risiko didefinisikan sebagai kombinasi dari kemungkinan suatu kejadian yang membahayakan atau paparan dan keparahan dari cidera atau sakit yang dapat disebabkan oleh kejadian atau paparan tersebut.

Setiap insiden yang terjadi di tempat kerja terdapat peluang, dapat digunakan skala berdasarkan tingkat potensinya. Peluang atau tingkat kemungkinan (Likehood) telah terstandar oleh AS/NZS 4360. Sedangkan, untuk menentukan konsekuensi terlebih dahulu membuat ketetapan severity yang berpotensi terjadi. Informasi yang terkumpulkan sejak tahap identifikasi, mencakup statistik insiden dan data lain. Tingkat keparahan (Severity) dapat diamati saat proses pekerjaan langsung.

Kombinasi perhitungan peluang dan konsekuensi pada Rate risiko menggunakan Rating setiap risiko, mengembangkan daftar prioritas risiko kerja. Sebuah tingkatan risiko ditentukan oleh hubungan antara hasil identifikasi bahaya dan konsekuensi.

Pengendalian risiko dilakukan pada seluruh bahaya yang ditemukan dalam proses identifikasi bahaya dan mempertimbangkan peringkat risiko untuk menentukan prioritas dan cara pengendaliannya. Dalam menentukan pengendalian harus memperhatikan hierarki pengendalian mulai dari eliminasi, substitusi, pengendalian teknis, administratif dan penyediaan alat keselamatan yang disesuaikan kondisi organisasi dan jenis bahaya.

Residual risk merupakan risiko sisa dari hasil pengendalian risiko yang telah dilakukan. Cara untuk mengetahui risiko tersebut adalah dengan melakukan perhitungan antara nilai risk assessment dikurangi nilai risk control. Apabila nilai hasilnya adalah $\leq 1$, maka bukan termasuk residual risk atau dengan kata lain risk control sudah bagus. Sedangkan jika nilai hasil dari pengurangan $>1$, maka termasuk residual risk dan memerlukan perbaikan risk control.

Berkembangnya daya saing produksi berbagai bidang usaha baik import dan eksport harus didukung pula dengan pemenuhan hak sumber daya manusianya. Tenaga kerja inilah yang menjadi pusat motor usaha produksi untuk menciptakan suatu barang yang berkualitas. Maka, salah satu hak bagi para pekerja adalah memperoleh pemenuhan kebutuhan Keselamatan dan Kesehatan Kerja selama kerja wajib terpenuhi oleh perusahaan (Sumakmur, 2001). Seperti, yang dicantumkan undang-undang RI pasal 8 no. 13 Tahun 2003 tentang Jaminan Sosial Ketenagakerjaan.

Sehingga bahaya yang ditimbulkan berupa kecelakaan, kebakaran, peledakan, pencemaran lingkungan dan PAK (Penyakit Akibat Kerja) dapat ditekan.

PT. Jamsostek, menyatakan dalam tahun 2012 untuk kasus kecelakaan kerja terjadi 99.491 kasus, di mana 90,85\% korban kecelakaan kembali sembuh; $4,15 \%$ mengalami cacat fungsi; $2,74 \%$ mengalami cacat sebagian, sisanya meninggal; mengalami cacat total, dan rata-rata terjadinya 414 kasus kecelakaan kerja setiap harinya. Sebagian besar atau sebanyak $70,74 \%$ kecelakaan tersebut terjadi di dalam lingkungan kerja, 18,32\% terjadi di jalan raya di perjalanan menuju dan dari tempat kerja, dan sisanya terjadi di luar tempat kerja. sekitar $85 \%$ Kecelakaan kerja disebabkan oleh faktor manusia sisanya $15 \%$ karena faktor lingkungan.

Perusahaan ini merupakan industri export sepatu kulit yang mengutamakan kualitas dalam proses produksinya. Dalam proses produksi di line upper atau tahapan awal pembuatan sepatu yang menggunakan mesin-mesin canggih tidak terlepas dari risiko terjadinya kecelakaan kerja. Terdapat tiga proses produksi sepatu antara lain bagian Line Upper atau kap sepatu, Line Injection atau penyuntikan sol sepatu, dan yang terakhir Line Finishing. Perusahaan yang memiliki tenaga kerja pada tahun 2014 sejumlah pekerja 7.053 tenaga kerja terdiri dari 1.244 pria dan 5.809 wanita.

Penghargaan yang berhasil diraih Perusahaan export sepatu dalam bidang K3 adalah Perusahaan memperoleh penghargaan Zero Accident pada Tahun 2010 dari Kementerian Tenaga Kerja dan Transmigrasi Republik Indonesia.

Program zero accident (kecelakaan nihil) ialah tanda penghargaan Keselamatan dan Kesehatan Kerja yang diberikan pemerintah kepada manajemen perusahaan yang telah berhasil dalam melaksanakan program Keselamatan dan Kesehatan Kerja sehingga mencapai nihil kecelakaan dan mencegah terjadinya kecelakaan kerja di tempat kerja tanpa menghilangkan waktu kerja

Meskipun tidak terjadi kecelakaan kerja fatal yang mengakibatkan hilangnya waktu kerja sebanyak 6.000.000 jam kerja selama tiga tahun 
berturut-turut, masih terdapat kecelakaan kerja yang terjadi di perusahaan.

Total kecelakaan kerja pada tahun 2013 di Perusahaan export sepatu, khususnya di bagian produksi line upper terdapat 55 kasus kejadian kecelakaan kerja. Mulai dari tahapan awal atau cutting hingga tahap akhir yaitu Two molding. Hal tersebut dapat berdampak besar untuk kesehatan karyawan jika tidak ada tindakan preventif. Berikut ini hasil report accident pada bagian line upper :

Tabel 1. Report Accident, Tahun 2014

\begin{tabular}{lc}
\hline \multicolumn{1}{c}{ NAMA MESIN/ KONDISI } & $\begin{array}{c}\text { JUMLAH KEJADIAN } \\
(\%)\end{array}$ \\
\hline CUTTING $=6$ & $10 \%$ \\
SKIVING $=10$ & $18 \%$ \\
STITCHING $=8$ & $14 \%$ \\
EMBOSS LOGO =5 & $9 \%$ \\
ROVING $=6$ & $10 \%$ \\
PUNCHING HOLE $=5$ & $9 \%$ \\
JUKI $=3$ & $5 \%$ \\
BRUSHING EDGE $=4$ & $7 \%$ \\
HAMMER OVER LAPING $=8$ & $14 \%$ \\
TWO MOLDING $=0$ & 0 \\
\hline TOTAL Kejadian KK = 55 & $100 \%$ \\
\hline
\end{tabular}

Sumber: Perusahaan Export Sepatu, 2013

Sebanyak 109 karyawan perusahaan export sepatu tahun 2013 terdapat penyakit akibat kerja. $34 \%$ karyawan mengalami luka robek, $15 \%$ karyawan penyakit kulit, $12 \%$ karyawan rasa nyeri dijari tangan, 12\% karyawan luka memar, 6\% karyawan luka bakar, 5\% karyawan luka tusuk, 5\% karyawan luka lecet ringan, 4\% karyawan robeknya kuku tangan dan sisanya 7\% karyawan mengalami gangguan ergonomi.

Data sekunder perusahaan menunjukkan bahwa kecelakaan yang sering terjadi yaitu pada karyawan line upper. Kejadian kecelakaan kerja pada pekerjaan line upper di Perusahaan export sepatu ini dapat dikatakan tergolong tinggi, sebab dari data sekunder pada tahun 2013 total 109 karyawan yang mengalami kecelakaan kerja. Dengan angka kejadian kecelakaan kerja karena luka robek, disebabkan oleh Operator saat mengganti skochi masih dalam keadaan mesin swift- on dan ketika ada karyawan lain lewat tidak sengaja akhirnya tersenggol dan menyentuh pedal mesin sehingga memicu jarum tersebut merobek tangan operator.

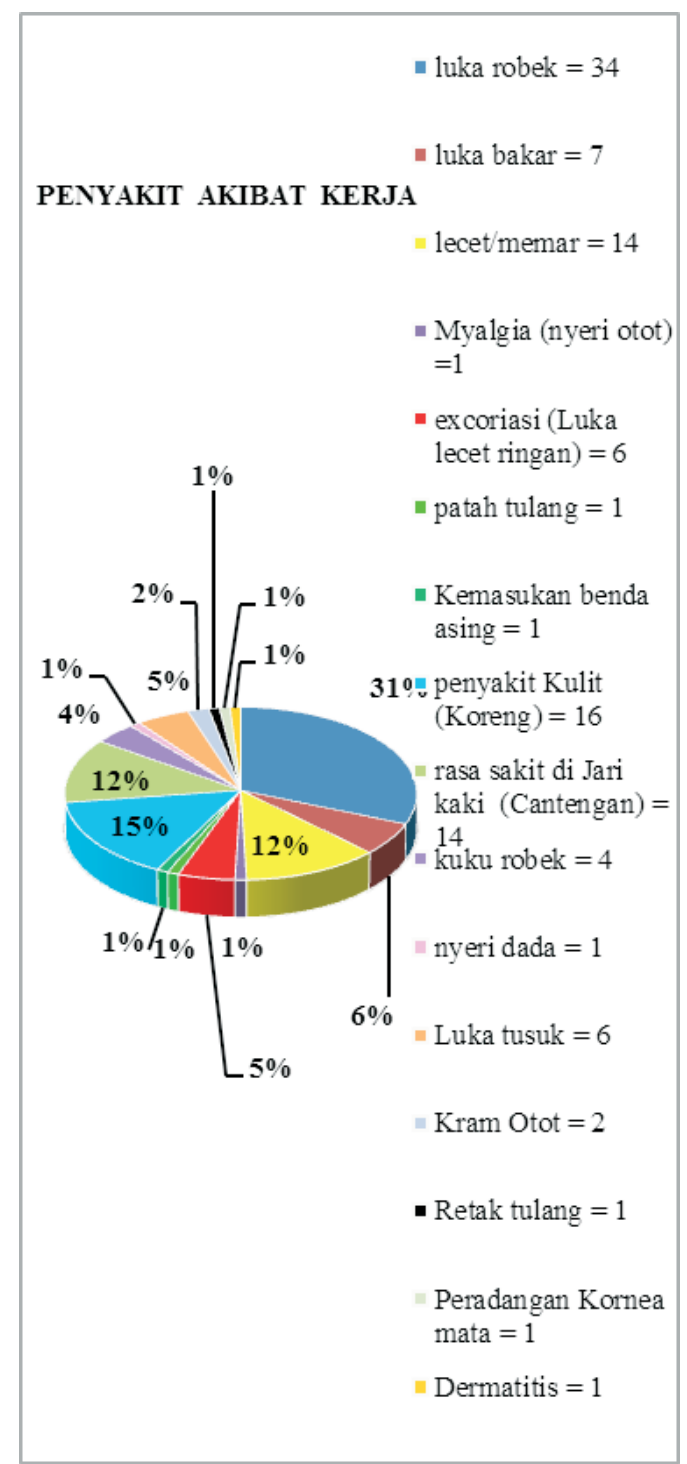

Gambar 1. Report Kejadian Kecelakaan Kerja Hall Produksi

Sumber: Perusahaan Export Sepatu, 2013.

Salah satu bagian proses produksi sepatu tahapan awal adalah line upper yang selanjutnya melewati bagian desma dan terakhir finishing. Pada line upper terdapat 10 mesin. Proses produksi di perusahaan elite ini mengutamakan mutu, sehingga tidak diperjualbelikan bebas di Indonesia. Adapun outlate sepatu khusus penjualan ini yang terdapat di Jakarta.

Perusahaan export sepatu ini telah melakukan upaya penilaian risiko yaitu dengan menggunakan metode FTA atau Fault Three Analysis. Teknik ini pada prinsipnya adalah mengidentifikasi sumber bahaya yang muncul setelah kecelakaan kerja. Dalam hal ini peneliti mencoba melakukan penilaian risiko dengan metode lain yaitu Job Safety Analysis 
atau JSA, untuk menginvestigasi bahaya setiap pekerjaan yang berisiko tinggi maupun pekerjaan yang baru.

Salah satu metode proaktif yaitu manajemen risiko. Manajemen risiko sebagai syarat mutlak untuk memastikan sebuah sistem manajemen K3 di suatu organisasi akan efektif dan tepat target untuk menurunkan angka kecelakaan kerja. Pada manajemen risiko dalamnya terdapat Risk Assessment yang mempelajari secara menyeluruh di tempat kerja untuk mengidentifikasi halhal, situasi, proses, yang dapat menyebabkan kerusakan, terutama kepada orang-orang. Setelah identifikasi dilakukan, mengevaluasi seberapa besar kemungkinan dan berat risikonya, dan kemudian memutuskan apa langkah-langkah yang harus berada di tempat untuk mencegah atau mengontrol bahaya yang terjadi secara efektif.

Risk assessment ditujukan menurunkan risiko hingga tingkat risiko yang bisa diterima. Langkah tepat manajemen risiko keselamatan kerja dapat menurunkan angka kecelakaan kerja yang mampu meningkatkan produktivitas kerja organisasi dan meminimalisir kecelakaan kerja.

Perusahaan export sepatu adalah salah satu perusahaan yang bergerak di bidang industri besar yang memproduksi berbagai jenis sepatu berbahan dasar kulit hewani. Terdapat tiga proses produksi sepatu antara lain bagian Line Upper atau kap sepatu, Line Injection atau penyuntikan sol sepatu, dan yang terakhir Line Finishing.

Perusahaan yang memiliki tenaga kerja pada tahun 2014 sejumlah pekerja 7.053 tenaga kerja terdiri dari 1.244 pria dan 5.809 wanita. Proses produksi yang terus-menurus beroperasi selama 24 jam dan memiliki waktu istirahat 1 jam selama 2 kali, yaitu saat istirahat siang dan saat pergantian shift pekerja, sehingga menimbulkan potensi bahaya yang cukup tinggi.

Mengingat masih tingginya risiko kecelakaan pada pekerjaan di bagian produksi khususnya line upper. Maka berdasarkan uraian diatas maka penulis tertarik untuk melakukan penelitian mengenai risk assessment (identifikasi bahaya, penilaian risiko dan pengendalian risiko) di Perusahaan export sepatu pada bagian line upper sebagai upaya mengidentifikasi faktor risiko bahaya hingga risiko sisa.

Dalam penelitian ini tujuan khusus meliputi: Mengidentifikasi bahaya pada bagian produksi line upper Perusahaan export sepatu, Mempelajari penilaian risiko pada bagian produksi line upper perusahaan export sepatu, mempelajari pengendalian risiko pada bagian produksi line upper perusahaan export sepatu, dan melakukan penilaian risiko sisa pada bagian produksi line upper perusahaan export sepatu.

\section{METODE}

Job Safety Analysis adalah sebuah metode proses mengidentifikasi bahaya, menilai risiko dan mengevaluasi risiko yang muncul dari sebuah bahaya, lalu menghitung kecukupan dari tindakan pengendalian yang ada dan memutuskan apakah risiko yang ada dapat diterima atau tidak (Ramli, 2010). Definisi lain Job Safety Analysis adalah suatu proses di mana sumber bahaya kebakaran dan peledakan yang ada dari setiap langkah pekerjaan teridentifikasi, risiko terukur dan pengendalian risiko dilakukan untuk mengurangi risiko terhadap personil, lingkungan dan harta benda

Ruang lingkup pembahasan berkaitan dengan design area kerja, proses, instalansi, mesin, peralatan pelindung diri, prosedur dan organisasi. Pemilihan metode yang akan digunakan saling tergantung pada bahan dan proses, tahapan dalam daur hidup sistem juga keterampilan dan pengalaman hidup dalam tim (Kuntoro, 2007).

Metode Job Safety Analysis terdiri dari 4 langkah yaitu Menyeleksi Pekerjaan yang akan dianalisis atau diprioritaskan berdasarkan tingkat keseringan dan tingkat keparahan, Menguraikan urutan proses pekerjaan, Identifikasi potensi bahaya pada setiap tahap pekerjaan dan Identifikasi potensi bahaya pada setiap tahap pekerjaan menetapkan upaya pengendalian bahaya.

Menurut Notoatmodjo (2010), berdasarkan cara pengambilan data penelitian ini menggunakan rancangan cross sectional, karena pengumpulan data dilakukan sekaligus pada saat itu juga. Sifat penelitian ini secara observasional. Berdasarkan analisis maka, penelitian ini merupakan penelitian deskriptif yaitu menggambarkan proses tanpa melakukan analisis hubungan variabel.

Populasi penelitian ini adalah karyawan pada bagian Line upper Perusahaan export sepatu sebanyak 12 orang. Pengambilan sampel untuk penelitian ini berasal dari 10 operator mesin, 1 orang Assistant Production Coordinator dan 1 orang Divisi Environment Health Safety.

Lokasi penelitian pada bagian line upper perusahaan export sepatu di Jawa Timur. Lokasi ini 
dipilih sebagai lokasi penelitian karena belum pernah sebelumnya dilakukan. Dalam pelaksanaannya pada bulan Maret 2014 hingga November 2014.

Variabel penelitian yang digunakan yaitu aktivitas produksi, bahaya, identifikasi bahaya, penilaian risiko, pengendalian risiko, risiko sisa atau residual risk.

Pengukuran identifikasi bahaya menggunakan metode Job safety Analysis (JSA). Selanjutnya diolah untuk menghitung Risk assessment berdasarkan perhitungan Risk Assessment Matrix (RAM).

Data yang dikumpulkan dalam penelitian ini adalah data primer dan data sekunder. Data primer didapat melalui hasil wawancara dan observasi. Wawancara dilakukan dengan operator dari 10 mesin dan Assistant Production Coordinator. Observasi dilakukan untuk mendapat proses kerja, bahaya dan risiko yang ada di area kerja. Data sekunder diperoleh melalui laporan Keselamatan dan Kesehatan Kerja (K3). Selanjutnya didokumentasi diperoleh yang berupa informasi sebagai penunjang penemuan-penemuan kasus dan selanjutnya untuk analisis data penelitian

Data hasil wawancara dan observasi Kemudian dianalisis dengan metode kualitatif, di mana penjelasan dari data hasil penelitian dideskripsikan dan dirangkum dengan berbagai variabel yang diidentifikasi sebelumnya.

\section{HASIL}

Identifikasi bahaya dilakukan pada 10 mesin (Cutting, Skiving, Stitching, Emboss Logo, Roving, Punching Hole, Juki, Brushing Edge, Hammer Over Lapping dan Two Molding ) menggunakan metode lembar observasi JSA.

Setelah dilakukan identifikasi bahaya pada bagian line upper Perusahaan export sepatu, langkah selanjutnya adalah melakukan penilaian risiko atau risk assessment. Dalam melakukan risk assessment terdapat dua tahap yaitu analisis dan evaluasi risiko. Seperti tampak pada Tabel di bawah ini:

Tabel 2. Lembar Identifikasi Bahaya (JSA), Tahun 2014

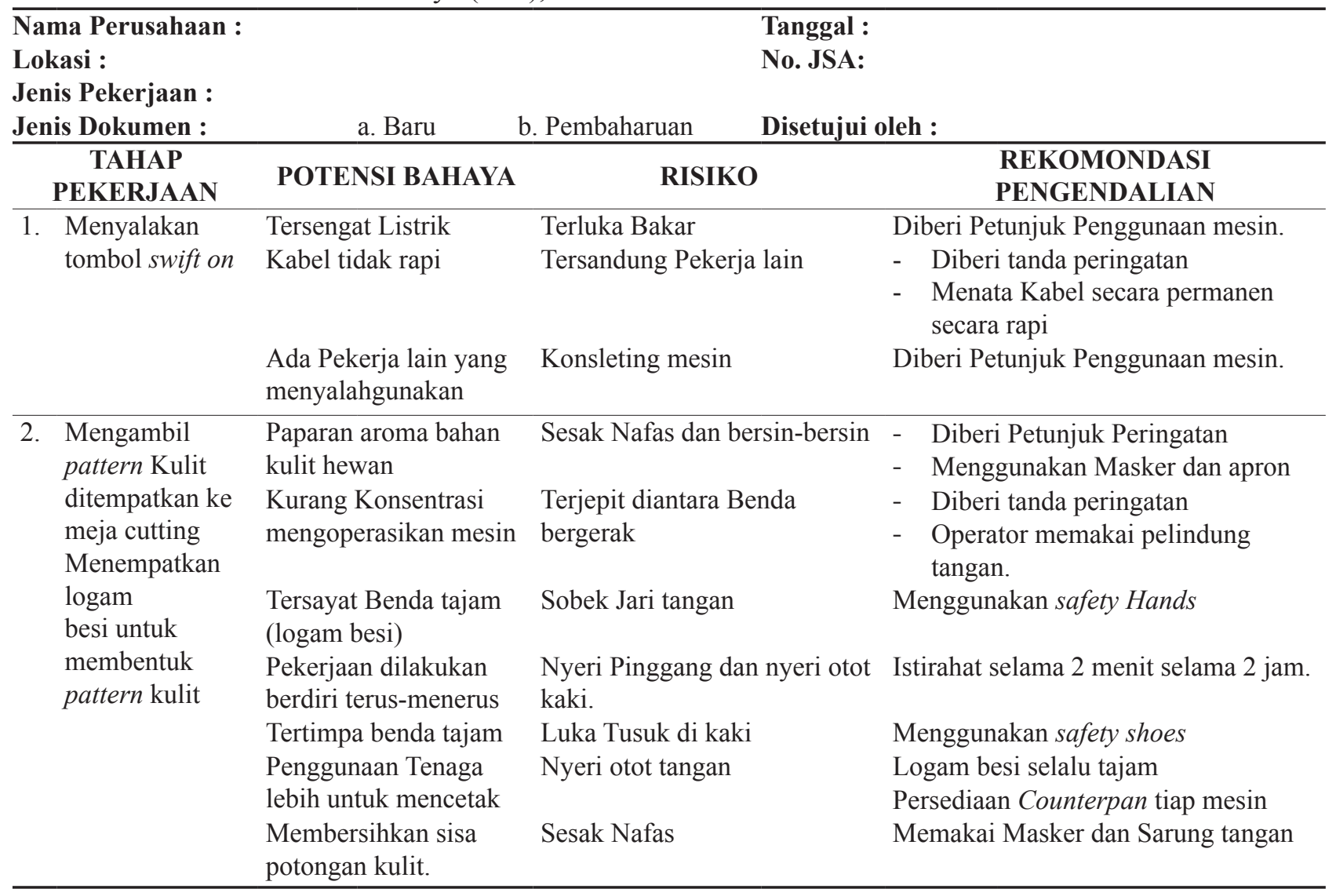


Pada Tabel 2 merupakan salah satu dari beberapa tabel mengidentifikasi potensi bahaya pada line upper dengan metode JSA dengan dipandu oleh salah satu Petugas K3 sehingga informasi yang didapat terarah.

Berdasarkan hasil identifikasi bahaya diperoleh potensi bahaya pada 10 mesin di line upper sebanyak 91 potensi bahaya dan menimbulkan 91 risiko dan ditemukan 7 temuan high risk dan 5 temuan untuk low risk.

Hasil Identifikasi bahaya pada pengoperasian mesin cutting atau pemotongan kulit hewan, dilakukan berdasarkan 2 tahap pekerjaan (menyalakan tombol swift on dan kedua pengambilan bahan kulit) yang dilakukan pekerja setiap hari selama 8 jam. 2 tahapan tersebut memiliki potensi bahaya tersendiri, yang paling berisiko adalah terpapar aroma bahan kulit hewan

Pengoperasian mesin skiving pada prinsip kerjanya penghalusan dan penipisan sisi kulit. Terdapat empat tahapan pekerjaan yaitu menyalakan tombol swift on, pengaturan mesin, menginjak pedal kaki, dan proses cleaning blower. Yang berisiko sedang yaitu bahaya mesin hingga berisiko robek kulit.

Pada proses stitching pola-pola kulit dan dijahit secara beraturan. Prinsip mesin yaitu seperti mesin jahit. Potensi bahayanya adalah kejatuhan benda padat dan bahaya kebisingan.

Pada pengoperasian mesin emboss logo terdapat beberapa potensi bahaya yang tinggi yaitu bising dan terpapar panas.

Pada pengoperasian mesin roving terdapat beberapa potensi bahaya yang termasuk risiko tinggi adalah bahaya bising, terpapar benda tajam dan panas.

Pada pengoperasian mesin punching hole dan brushing edge pada prinsipnya menggunakan tekanan benda padat sehingga mengaitkan antara pattern dengan artikel. Bahaya yang termasuk tinggi adalah bising.

Pada pengoperasian mesin Juki terdapat potensi tertusuk jarum jahit dan terjepit mesin skochi yang dapat meremukkan jari tangan.

Pada pengoperasian mesin hammer over lapping adanya bahaya kebisingan dan terpapar panas. Sehingga cenderung cepat lelah.

Pada pengoperasian mesin two molding memiliki potensi yang tidak berisiko fatal, hanya saya mesin ini menggunakan 2 temperatur (suhu panas $180^{\circ} \mathrm{C}$ dan suhu dingin $25^{\circ} \mathrm{C}$ ).
Pada kondisi lingkungan industri seperti ini tidak menutup kemungkinan bahaya lain (Swasti, 2013), sehingga pengukuran terhadap bahaya yang dicuragai dapat diketahui, seperti data pengukuran area kebisingan pada bagian line upper.

Tabel 3. Pengukuran Intensitas Kebisingan, Tahun 2014

\begin{tabular}{clccc}
\hline \multirow{2}{*}{ Line } & \multirow{2}{*}{ Description } & \multicolumn{3}{c}{ Noise } \\
\cline { 3 - 5 } & & Min & Max & Avr \\
\hline ECCO 1 & Hammer over & 76,5 & $\mathbf{8 2 , 9}$ & 78,1 \\
& Lappimg & & & \\
& Stitching & 74,1 & $\mathbf{8 6 , 8}$ & 78,4 \\
& Roving & 73,5 & $\mathbf{9 2 , 1}$ & 84,7 \\
& Juki & 73,3 & $\mathbf{8 6 , 5}$ & 77,9 \\
\hline
\end{tabular}

Sumber: Perusahaan Export Sepatu, 2014

Pada tabel 3 menunjukkan hasil pengukuran intensitas kebisingan pada bagian line upper. Data sekunder tersebut dilakukan oleh tim EHS Perusahaan export sepatu dengan alat Sound Level Meter) yang menggunakan regulasi KepMenaker No. Kep-51/MEN/1999 mengenai paparan Nilai Abang Batas Kebisingan (intensitas tertinggi 85 dB) yang dianggap aman.

Pengukuran itu berdasarkan diperkirakan tingginya intensitas suara mesin. Dari Hasil tersebut dapat diketahui untuk sumber kebisingan yang mendekati $85 \mathrm{~dB}$ adalah Mesin Roving, sebab pada prinsipnya mesin tersebut menggunakan gerakan gerinda berputar secara terus-menerus yang berfungsi untuk menipiskan pattern yang akan dikaitkan.

Berdasarkan pelaksanaan hasil observasi dan wawancara identifikasi bahaya dilakukan terhadap 10 operator mesin di bagian produksi. Salah satu Penilaian risiko pada mesin cutting dapat dilihat pada Tabel 4.

Tabel 4 Risk Assessment pada salah satu mesin pada bagian line upper. Total yang teridentifikasi sebanyak 91 risiko (berjumlah 7 risiko high risk dan 5 risiko low risk), sedangkan, pada mesin yang tergolong berisiko tinggi adalah mesin Roving, dan yang tergolong berisiko rendah pada mesin Two molding.

Pada Mesin Roving untuk penilaian risiko ditemukan 3 jenis antara lain : risiko terkena gerinda apabila pengaturan mesin tidak sesuai dengan SOP, risiko terpapar bising dan terakhir terpapar panas

Mesin Two Molding untuk penilaian risiko hanya terdapat risiko sedang dan rendah. 
Tabel 4. Lembar Risk Assessment, Tahun 2014

\begin{tabular}{|c|c|c|c|c|c|c|c|c|c|}
\hline \multicolumn{10}{|c|}{ 1. CUTTING } \\
\hline & \multirow{2}{*}{$\begin{array}{c}\text { TAHAP } \\
\text { PEKERJAAN }\end{array}$} & \multirow{2}{*}{ POTENSI BAHAYA } & \multirow{2}{*}{ RISIKO } & \multicolumn{3}{|c|}{ Risk Assesment } & \multicolumn{3}{|c|}{ Evaluasi Risiko } \\
\hline & & & & $L$ & $S$ & $\mathbf{T}$ & (L) & (M) & (H) \\
\hline \multirow[t]{3}{*}{1} & \multirow[t]{3}{*}{$\begin{array}{l}\text { Menyalakan } \\
\text { tombol swift on }\end{array}$} & Tersengat Listrik & Terluka Bakar & $\begin{array}{l}\text { Rare } \\
\text { (1) }\end{array}$ & $\begin{array}{l}\text { Major } \\
(4)\end{array}$ & 4 & $\checkmark$ & & \\
\hline & & Kabel tidak rapi & $\begin{array}{l}\text { Tersandung } \\
\text { Pekerja lain }\end{array}$ & $\begin{array}{l}\text { Unlikely } \\
\text { (2) }\end{array}$ & $\begin{array}{l}\text { Major } \\
(4)\end{array}$ & 8 & & $\checkmark$ & \\
\hline & & $\begin{array}{l}\text { Ada Pekerja lain yang } \\
\text { menyalahgunakan }\end{array}$ & $\begin{array}{l}\text { Konsleting } \\
\text { mesin }\end{array}$ & $\begin{array}{l}\text { Rare } \\
(1)\end{array}$ & $\begin{array}{l}\text { Major } \\
(4)\end{array}$ & 4 & $\checkmark$ & & \\
\hline \multirow[t]{7}{*}{2} & \multirow{7}{*}{$\begin{array}{l}\text { Mengambil } \\
\text { pattern Kulit } \\
\text { ditempatkan ke } \\
\text { meja cutting } \\
\text { Menempatkan } \\
\text { logam } \\
\text { besi untuk } \\
\text { membentuk } \\
\text { pattern kulit }\end{array}$} & $\begin{array}{l}\text { Paparan aroma bahan } \\
\text { kulit hewan }\end{array}$ & $\begin{array}{l}\text { Sesak Nafas } \\
\text { dan bersin- } \\
\text { bersin }\end{array}$ & $\begin{array}{l}\text { Almost } \\
\text { certain } \\
(5)\end{array}$ & $\begin{array}{l}\text { Moderate } \\
\text { (3) }\end{array}$ & 15 & & & $\checkmark$ \\
\hline & & $\begin{array}{l}\text { Kurang Konsentrasi } \\
\text { mengoperasikan mesin }\end{array}$ & $\begin{array}{l}\text { Terjepit } \\
\text { diantara Benda } \\
\text { bergerak }\end{array}$ & $\begin{array}{l}\text { Possible } \\
\text { (3) }\end{array}$ & $\begin{array}{l}\text { Minor } \\
(2)\end{array}$ & 6 & & $\checkmark$ & \\
\hline & & $\begin{array}{l}\text { Tersayat Benda tajam } \\
\text { (logam besi) }\end{array}$ & $\begin{array}{l}\text { Sobek Jari } \\
\text { tangan }\end{array}$ & $\begin{array}{l}\text { Possible } \\
\text { (3) }\end{array}$ & $\begin{array}{l}\text { Major } \\
(4)\end{array}$ & 12 & & & $\checkmark$ \\
\hline & & $\begin{array}{l}\text { Pekerjaan dilakukan } \\
\text { berdiri terus-menerus }\end{array}$ & $\begin{array}{l}\text { Nyeri Pinggang } \\
\text { dan nyeri otot } \\
\text { kaki. }\end{array}$ & $\begin{array}{l}\text { Possible } \\
\text { (3) }\end{array}$ & $\begin{array}{l}\text { Insignifikan } \\
\text { (1) }\end{array}$ & 3 & $\checkmark$ & & \\
\hline & & Tertimpa benda tajam & $\begin{array}{l}\text { Luka Tusuk di } \\
\text { kaki }\end{array}$ & $\begin{array}{l}\text { Rare } \\
(1)\end{array}$ & $\begin{array}{l}\text { Minor } \\
\text { (2) }\end{array}$ & 2 & $\checkmark$ & & \\
\hline & & $\begin{array}{l}\text { Penggunaan Tenaga } \\
\text { lebih untuk mencetak }\end{array}$ & $\begin{array}{l}\text { Nyeri otot } \\
\text { tangan }\end{array}$ & $\begin{array}{l}\text { Unlikely } \\
\text { (2) }\end{array}$ & $\begin{array}{l}\text { Insignifikan } \\
\text { (1) }\end{array}$ & 2 & $\checkmark$ & & \\
\hline & & $\begin{array}{l}\text { Paparan sisa potongan } \\
\text { kulit. }\end{array}$ & Sesak Nafas & $\begin{array}{l}\text { Rare } \\
(1)\end{array}$ & $\begin{array}{l}\text { Moderate } \\
\text { (3) }\end{array}$ & 3 & $\checkmark$ & & \\
\hline
\end{tabular}

Setelah dilakukan penilaian risiko tahapan berikutnya adalah mempelajari upaya pengendalian berdasarkan Hierarki Pengendalian. (Ramli, 2010). Upaya pengendalian dapat dilihat pada Tabel 5.

Hasil pengendalian risiko dari masing-masing aktivitas pekerjaan 10 mesin yang dilakukan berdasarkan hasil wawancara dan observasi, untuk upaya pengendalian pada bagian Line upper Perusahaan export sepatu telah sesuai dengan hierarki pengendalian dengan sejumlah 91 pengendalian telah diaplikasikan dengan cukup baik. Pengendalian yang bernilai tinggi dan dianggap sebagai upaya terbaik adalah pengendalian isolasi kabel di line upper keseluruhan mesinmesin tersebut telah diberi tanda stiker peringatan bahaya mesin tersebut memiliki tekanan voltase yang tinggi.

Sedangkan, untuk upaya pengendalian yang belum diterapkan pada bagian Line upper Perusahaan export sepatu yaitu pada bahaya ergonomi seperti, memodefisikasi mesin, misalnya pada pekerjaanya memerlukan berdiri selama 8 jam kerja tanpa adanya kursi.
Analisa risiko sisa dari risk assessment hingga upaya pengendalian di bagian line upper perusahaan export sepatu ditemukan adanya 30 risiko sisa atau residual risk. Risiko sisa yang dihasilkan disebabkan masih belum diketahui upaya pengendalian maupun bahaya yang tidak diketahui oleh pihak terkait.

Berdasarkan hasil observasi lingkungan kerja di line upper risiko sisa disebabkan karena unsafe act yang tidak menaati SOP yang berlaku. Misalnya, pada mesin roving, bahaya debu dan suara bising. Hal tersebut tidak dihiraukan oleh operator mesin (tidak memakai masker, googles dan bahkan earplug). Perusahaan telah menyediakan APD seperti, earplug, masker dan googles namun masih terbatas.

Mesin yang memiliki risiko sisa tertinggi ada pada mesin Roving karena paparan debu gerinda jika tidak dibudayakan mematuhi SOP dalam pemakaian APD maka akan terjadinya penyakit akibat kerja jangka panjang dan untuk risiko sisa yang bernilai rendah ada pada mesin stitching yaitu perlu adanya kajian ulang SOP mengenai alat perlindungan tangan seperti perlu memakai finger shall atau sarung jari tangan. 


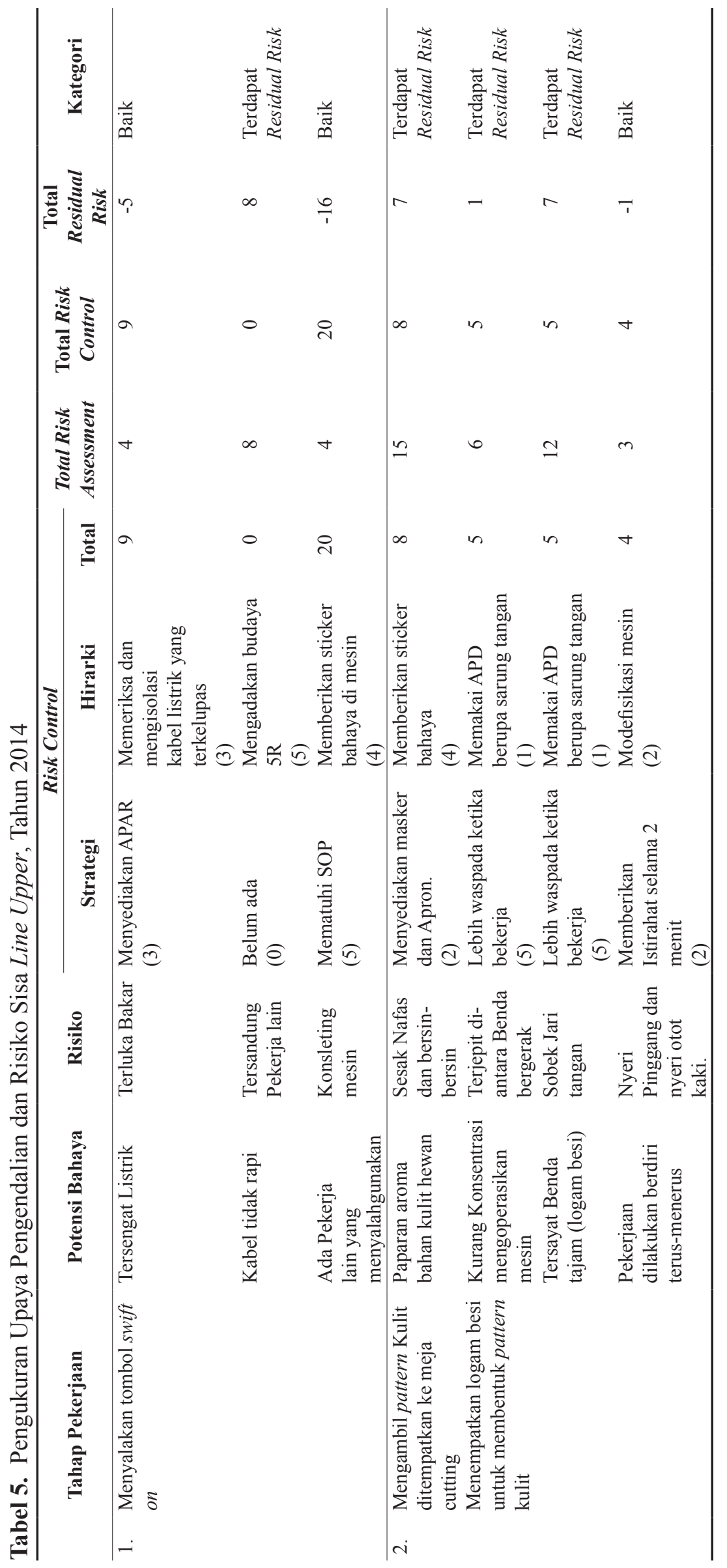




\section{PEMBAHASAN}

Penerapan risk assessment Perusahaan export sepatu menggunakan dua pendekatan yaitu, pertama dengan investigasi kecelakaan kerja dan kedua, dengan manajemen risiko. Risk assessment di Perusahaan export sepatu pada bagian Line upper mengidentifikasi bahaya, menilai risiko yang terjadi, melakukan pengendalian risiko hingga menghitung risiko sisa. Program HIRARC di Perusahaan export sepatu merupakan tujuan untuk mencapai zero accident dan telah dicapai. Pada tahun 2004 dan 2006 hanya pada penelitian sebelumnya mengutamakan manajemen bahaya, misalnya membuat pohon faktor yang selanjutnya dilakukan upaya pencegahan sesuai SOP melalui metode FTA.

Berdasarkan hasil observasi dan data sekunder pada lembar JSA penerapan risk assessment perusahaan export sepatu untuk identifikasi bahaya masih belum baik dalam hal terperinci hingga tahap perhitungan risiko sisa. Hal ini menyebabkan adanya kemungkinan lain bahaya yang masih jarang diketahui bahkan risiko bahaya kecelakaan dan kesehatan di lingkungan kerja.

Namun, dalam hal ini Perusahaan export sepatu ini, sudah menerapkan pencegahan kecelakaan dengan menerapkan SMK3 yang ditetapkan Dalam Peraturan Pemerintah Nomor 50 tahun 2012 tentang Penerapan Sistem Manajemen Kesehatan dan Keselamatan Kerja.

Menurut Ramli (2010), dalam melakukan identifikasi bahaya terdapat tiga teknik yang digunakan yaitu metode pasif, metode semiproaktif, dan metode proaktif. Identifikasi yang dilakukan di Perusahaan export sepatu sudah diupayakan secara sistematis baik perencanaan dan pelaporan kejadian kecelakaan ke Manajer EHS. Pada Hasil Identifikasi bahaya terdapat 41 tahapan pekerjaan di mana masing-masing tahapan memiliki risiko yang berbeda-beda. Hal tersebut bisa dipengaruhi oleh kondisi mesin, lingkungan dan manusianya.

Pengendalian risiko pada pengoperasian di bagian Line Upper telah memenuhi Hierarki pengendalian. Namun, karena ada beberapa bahaya yang belum diketahui oleh devisi EHS, maka peneliti mengembangkan pengendalian risiko agar tepat untuk mengendalikan risiko yang ada. Misalnya untuk mengendalikan risiko terluka bakar akibat tersengat aliran listrik dari kabel yang terkelupas, maka dilakukan pengendalian yakni operator diwajibkan untuk lebih berhati-hati ketika bekerja serta memakai alat pelindung diri berupa safety shoes untuk mencegah kontak langsung dengan bumi dan memakai sarung tangan untuk mencegah kontak langsung dengan aliran listrik.

Perhitungan risiko sisa yang telah dilakukan oleh peneliti menghasilkan sejumlah risiko sisa. Hal ini dikarenakan beberapa pengendalian yang dilakukan tidak mencukupi untuk mengendalikan risiko yang ada. Setelah dilakukan perhitungan risiko sisa ternyata terdapat 30 risiko sisa dari keseluruhan mesin ditemukan dan dikelompokkan menjadi 14 risiko.

Sebagian besar risiko yang menghasilkan risiko sisa berhubungan dengan Human error. Risiko yang berhubungan dengan Pengendalian yang bisa disarankan peneliti pada perusahaan adalah Pengendalian secara Teknik dan administratif. Seperti, memodefisikasi mesin (penambahan intensitas pencahayaan pada mesin yang membutuhkan ketelitian) dan sosialisasi berkala management risk pada seluruh karyawan perusahaan.

\section{SIMPULAN}

Setiap tahapan pembuatan kap sepatu di Perusahaan export sepatu ini menggunakan mesin-mesin berteknologi canggih. Setiap tahapan pekerjaan tidak terlepas dari potensi bahaya kesehatan dan keselamatan kerja.

Dalam pelaksanaan observasi mengenai Identifikasi bahaya pengoperasian terhadap 10 mesin yaitu Cutting, Skiving, Stitching, Embos Logo, Roving, Punching Hole, Juki, Brushing Edge, Hammer Over Lapping, dan Two Molding pada line upper teridentifikasi sebanyak 41 tahapan pekerjaan.

Pada Mesin yang tergolong berisiko tinggi bahayanya adalah mesin Roving, sedangkan yang tergolong berisiko rendah potensi bahaya ada pada mesin Two molding.

Hasil Penilaian risiko keseluruhan dari 10 mesin pada line Upper Perusahaan export sepatu diketahui dari aktivitas tersebut teridentifikasi 91 risiko: Keseluruhan mesin tersebut memiliki risiko terjadinya kecelakaan kerja, sehingga dilakukan klasifikasi risiko terdapat 7 temuan risiko high risk dan terdapat 5 temuan risiko dengan hasil low risk pada semua mesin.

Pada mesin roving untuk penilaian risiko ditemukan 3 jenis antara lain: risiko terkena gerinda apabila pengaturan mesin tidak sesuai dengan SOP, 
risiko terpapar bising dan terpapar panas. Sedangkan, mesin Two Molding untuk penilaian risiko hanya terdapat risiko sedang dan rendah.

Upaya pengendalian dari 10 mesin pada bagian line upper telah sesuai dengan Hierarki pengendalian sejumlah 91 pengendalian, yang telah diaplikasikan dengan cukup baik.

Risiko sisa dari keseluruhan mesin pada bagian line upper Perusahaan export sepatu masih menyisakan sebanyak 30 risiko sisa.

\section{DAFTAR PUSTAKA}

Alli, Benjamin O. 2008. Fundamental Principal of Occupational Health and Safety Second Edition. Geneva. ILO.

Coppee, Georges H. 2013. Occupational Health Service and Practice. http://www.ilo.org/safework bookshelf/english?content\&nd=857170174. International Labor Organization (Sitasi 6 Mei 2013)

Depnakertrans RI. 2006. Himpunan Peraturan Perundang-undangan Keselamatan dan kesehatan Kerja. Depnakertrans RI . Jakarta.

Ilfani, Grisma. 2013. Analisis Pengaruh Keselamatan dan Kesehatan Kerja terhadap Kinerja Karyawan. (Studi pada PT. APAC Inti Corpora Bawean Jawa Tengah Unit Spinning2). Skripsi. Universitas Diponegoro. Semarang.

Joint Technical CommitteeOB-007, Risk Management. 2004. AS/NZS 4360:2004 Australian/New Zealand Standard Risk Management. Sydney.

Standards Australia International Ltd, G.

Katindo Megah Utama. 2011. Himpunan Peraturan Perundang-undangan Keselamatan dan Kesehatan Kerja. Jakarta.

Jamsostek, PT. 2013. Transforming Into New Era(Transformasi Menuju Era Baru).Jamsostek http://www.jamsostek.co.id/content/i. php?mid=5\&id=47. (Sitasi 5 Maret 2013)
OSHA. 2002. Job Hazard Analysis. US Departement of Labor. Occupational safety and health administration. OSHA-30171. USA.

Kuntoro, Haji. 1948. Metode statistik. Pustaka Melati 2007. Surabaya.

Sand, Agung. 2009. HIRARC Sebagai Upaya Pengendalian Kecelakaan Kerja Perusahaan di Sidoarjo Jawa Timur. Skripsi. Universitas Airlangga.

Swasti, Nadia. 2013. Risk management pada pekerjaan pengoperasian dan perawatan passenger hoist jenis SC 160/160. (Studi Kasus di Proyek Pengembangan Bandara Internasional Ngurah-Rai Bali (PPBIB) KSO Adhi - Wika). Skripsi. Universitas Airlangga.

Musoffan, Wildan. 2007. Analisa Aspek Keselamatan dan Keehatan Kerja (K3) Dalam Upaya Identifikasi Potensi Bahaya di Unit Plastic Injection di PT. Astra Honda Motor. Jakarta.

Notoatmodjo, Soekidjo. 2010. Metodologi Penelitian Kesehatan. Jakarta: Rineka Cipta.

Pratama, Zakka Setya. 2012. Risk Management Pada Pekerja Oxy-LPG Material Cutting di Area Workshop PT Bangun Sarana Baja Gresik. Skripsi. Universitas Airlangga.

Nuraga, Wisnu 2008. Dermatitis Kontak pada Pekerja yang Terpajan dengan Bahan Kimia di Perusahaan Industri Ototmatif Kawasan Industri. Skripsi. Cibitung. Jawa Barat.

Ramli, Soehatman. 2010. Sistem Manajemen Keselamatan \& Kesehatan K3 OHS Risk Management. Jakarta: Dian Rakyat.

Ramli, Soehatman. 2010. Pedoman Praktis Manajemen Risiko Dalam Perspektif Kerja OHSAS 18001. Jakarta: Dian Rakyat.

Suma'mur. 2009. Higiene Perusahaan dan Kesehatan Kerja (Hiperkes). Jakarta: Sagung Seto.

Tarwaka. 2010. Ergonomi Industri Dasar-dasar Pengetahuan Ergonomi dan Aplikasi di Tempat Kerja. Solo: Harapan Press. 